\title{
MIL Competency Framework: Mapping Media and Information Competencies*
}

\author{
Tomás Durán-Becerra** \\ Jesús Lau ${ }^{* * *}$ \\ Received: 2020-02 05 - Sent to peers: 2020-03-05 \\ Peer Approved: 2020-04-07 • Accepted: 2020-05-2 2 \\ https://doi.org/10.22395/angr.v19n37a3
}

\begin{abstract}
This article explores a literature review on different proposals to assess media and information literacy (MIL) competencies in citizens seeking to define the fundamental MIL skills and competencies to be considered in national curricula and assessment schemes. The study is based on qualitative content analysis to map and systematize the main MIL frameworks, research reports, and their practical applications/experiences. This qualitative technique allows the combination of categories (dimensions) and correlation of individual indicators (skills and capabilities) to group subcategories (components). The study inquires Unesco's framework, as well as the authors upon which this theoretical approach was built, together with the European Commission's views on media education. It gathers their principal propositions on media competence assessment and sets a reflection on information literacy and Educommunication as a contribution strongly developed in the Ibero-American context. A broad analysis of digital competencies related to media and information literacy is also included in the study. A new interpretation is given to the studied concepts to draw a structured systematization of competences on media and information literacy that sets a framework to assess and design MIL programs, actions or curricula. Finally, it proposes a map of skills and competences in MIL that allows the future creation of methodologies and strategies for the visibility, promotion, strengthening or evaluation of MIL.
\end{abstract}

Keywords: media education; media literacy; information literacy; digital literacy; access to information; assessment methods; life skills; educational indicators.

\footnotetext{
" This article shows the results of the Ph.D. project "MIL in Latin America. Approximation, analysis, and assessment proposal of Media and Information Literacy in Latin America" (Durán-Becerra, 2016), developed at the Universidad Autónoma de Barcelona from 2013 to 2016. It also includes a reconceptualization and systematization of MIL frameworks based on the participation of the authors in the Unesco-UNAoC Milid Network (Unitwin), a research consortium on MIL that gathers twenty-four universities from around the world in Spain.

" Research Director at the Corporación Unificada Nacional de Educación Superior (CUN), Bogotá, Colombia. PhD in Communication and Journalism from the Universidad Autónoma de Barcelona. Member of Unesco-UNAoC Milid Network. Email: tomasduranb@gmail.com; Orcid: https://orcid.org/0000-0002-5332-8785

"** Researcher at Universidad Veracruzana, Mexico. PhD in Information Science, University of Sheffield, England. Email: jesuslau@gmail.com; Orcid: https://orcid.org/0000-0001-7952-2204
} 


\title{
Marco de Competencias AMI: Mapeando los Medios y la Competencia Informacional
}

\begin{abstract}
Resumen
Este artículo explora mediante la revisión de diferentes propuestas para la evaluación de las competencias en alfabetización mediática informacional (AMI) en ciudadanos que buscan definir las habilidades AMI fundamentales para ser considerados en los esquemas de evaluación y los currículos nacionales. El estudio está basado en un análisis cualitativo de contenido para mapear y sintetizar los marcos AMI principales, reportes de investigación y sus experiencias/aplicaciones prácticas. Esta técnica cualitativa permite la combinación de categorías (dimensiones) y la correlación de indicadores individuales (habilidades y capacidades) a subcategorías grupales (componentes). El estudio examina el marco de la UNESCO, así como a los autores sobre los que este enfoque teórico está fundamentado, junto a las visiones de la Comisión Europea sobre la educación mediática. El estudio recopila sus principales propuestas sobre la evaluación de competencias mediáticas y sienta una posición reflexiva sobre la alfabetización y la Educomunicación como una contribución fuertemente desarrollada en el contexto Iberoamericano. Un análisis general de las competencias relacionadas con la alfabetización informacional también está incluido en este estudio. Se da una nueva interpretación a los conceptos estudiados para delinear una sistematización estructurada de las competencias mediáticas y la alfabetización informacional que establece un marco para la evaluación y el diseño de programas, acciones y currículos AMI. Finalmente, propone un mapa de habilidades y de competencias AMI que permite la creación de futuras metodologías y estrategias para la visibilización, promoción, fortalecimiento o evaluación de las AMI.
\end{abstract}

Palabras clave: educación mediática; alfabetización mediática; alfabetización informacional; alfabetización digital; acceso a la información; métodos de evaluación; habilidades para la vida; indicadores educacionales.

\section{Marco de avaliação global da alfabetização midiática e informacional (AMI): mapeamento das competências midiáticas e informacionais}

\begin{abstract}
Resumo
Este artigo explora uma revisão da literatura sobre diferentes propostas para avaliar as competências midiáticas e informacionais (AMI) dos cidadãos a fim de definir as habilidades e competências AMI fundamentais para serem consideradas em currículos nacionais e esquemas de avaliação. Este estudo está baseado na análise qualitativa de conteúdo para fazer um mapeamento e síntese dos quadros principais de AMI, relatórios de pesquisa e suas aplicações práticas/experiências. Essa técnica qualitativa permite a combinação de categorias (dimensões) e a correlação de indicadores individuais (habilidades e capacidades) para agrupar subcategorias (componentes). O estudo indaga o marco de avaliação da Unesco, como também autores sobre os quais essa abordagem teórica foi construída, junto com a visão da Comissão Europeia sobre a educação midiática. Reúne suas posturas principais sobre a avaliação da competência midiática e propõe uma reflexão sobre a alfabetização midiática e a Educomunicação como uma contribuição desenvolvida fortemente no contexto ibero-americano. Uma análise ampla das competências digitais relacionadas à alfabetização midiática e informacional também foi incluída no estudo. Uma nova interpretação é dada aos conceitos estudados para desenhar uma sistematização estruturada das competências para a alfabetização midiática e informacional que estabelece um quadro para avaliar e modelar programas de AMI, ações e currículos. Finalmente, propõe um mapa de habilidades e competências na AMI que permite a criação futura de metodologias e estratégias para a visibilidade, a promoção, o fortalecimento ou a avaliação da AMI.
\end{abstract}

Palavras-chave: educação midiática; alfabetização midiática; alfabetização informacional; alfabetização digital; acesso à informação; métodos de avaliação; habilidades para a vida; indicadores educacionais. 


\section{Introduction}

Citizen interaction with large sets of information and media content has increased nowadays as the traditional industry and new players nurture the media and information landscapes with contents of different types and diverse production methods (curation and validation). The inclusion of new information providers, user-generated content, public (government) information, among others, opens the range of delivered and consumed information in terms of its scope and quality (Orozco, 1997). In this context, digital citizens -as can be regarded- are exposed to several sources of information, media, and cultural products and. They, therefore, are also exposed to the opportunities and risks associated to misinformation, fake news, low-quality content, and other problems generated by the lack of media competence.

In response to this increasingly mediated and challenging scenario, international organizations, researchers, scholars and some governments have seen media and information literacy (MIL) as a way to foster media awareness and empower citizens towards information inputs (Durán-Becerra \& Tejedor-Calvo, 2017; Petranová, Hossová, E Velický, 2017; Leaning, 2017, pp. 117-127; Literat, 2014). In this regard, media competence, as fostered by MIL, implies that citizens ought to gain the capacity to interact, understand, use, transform and create information in an advanced, critical and transparent way, a capability not granted by the mere acquisition of technical skills or the use of the latest information and communication technologies (Giraldo-Luque, Villegas-Simón, E Durán-Becerra, 2017; Lopes, Costa, Araujo, E Ávila, 2018).

Media and information literacy (MIL) is a concept based on many notions and trends, an initiative of Unesco (2008, 2011a; 2011b, 2013) that aims to create a holistic understanding with a broad theoretical proposition grounded in current trends from both fields (media and information). The last ten years have been of crucial importance for Unesco's MIL theoretical positioning and concept promotion , as well as for defining related competences. The objective of this organization is to converge in a single discipline the different approaches to MIL (Lau \& Grizzle, 2020). This paper therefore aims to identify the conceptualization of MIL in the still-incipient literature produced around this merged concept, where two objectives of similar competences become related in their inherent skills and minor different processes.

The concept of MIL refers to both processes of understanding and use of media (media and information) as well as the use of the digital Information and Communications Technologies (ICT) (Wilson, 2012, p. 16; Koltay, 2011). It seeks to include the generation of competencies for critical comprehension and understanding to make informed decisions and comprehend the functioning of media and technology in general (Culver $\&$ Jacobson, 2012). It emphasizes the ethical treatment of media, 
information and technology, and their capacity to contribute in a positive way to democracy and to the empowerment of citizens. As Wilson (2012) declares:

MIL also involves an awareness of the right to access information, as well as the importance of using information and technology ethically and responsibly to communicate with others. Today, technology enables individuals to participate in intercultural dialogue as members of a "global village". Within this "village", possibilities for global citizenship can be explored, as responsible use of media and technology moves users from critical autonomy to critical solidarity as they connect with people from around the world. (p. 18)

The scope and complexity of MIL have also been taken into account by the European Commission (2007; 2009), an institution which has generated guidelines and funded research on the subject (Frau-Meigs, 2012; Petranová et al., 2017), along with Unesco (2013, p. 47), to promote and assess MIL. In regard to Unesco, the evaluation proposal includes two levels. The first corresponds to the general framework of the context a nation must have to promote the development of MIL competencies, followed by a second level which defines the set of basic skills that ought to be achievable. The European framework (Celot \& Pérez, 2009, pp. 34-50) also includes two levels: it labels the first one as environmental factors, with an intention similar to that of Unesco, followed by the elements which integrate the personal competencies, although it does not include the skills of creating and sharing in a specific and clear way that the United Nations agency does. Studies such as Emedus (Durán-Becerra \& Tejedor-Calvo, 2015; Petranová et al., 2017), ANR Translit (Frau-Meigs, 2012), and COST "Transforming Audiences, Transforming Societies" (Frau-Meigs, Vélez \& Michel, 2017) also highlight these merging points. In essence, both propositions coincide in their general proposal, stating that for MIL evaluation, it is necessary to assess both the general framework/ context of a country and individual competences of its citizens (table 1).

The Association of College and Research Libraries (Association of College and Research Libraries [ACR L], 2000, pp. 4-5), a leader and advocate of Information Literacy (IL), also defines the importance of acquiring skills and abilities leading to permanent learning in formal spaces of education, whereas an outcome ought to foster skills to locate, use, arrange and assess/value the required information (information need). Libraries, as actors of vital importance in the process, have undertaken the facilitation of IL (Uribe-Tirado, 2010; Ponjuán, Pinto, E Uribe-Tirado, 2015).

Governments, also as key actors, are or ought to be in charge of designing policies aimed toward the development of IL (Frau-Meigs, 2012). Media Literacy (ML) in turn, has been thoroughly developed by actors such as the Australian Curriculum, Assessment and Reporting Authority (Acara), which, in the framework of the National Assessment Plan (NAP), identifies evaluation elements related to ML and 
Table 1. Unesco's Framework and European Framework

European and Unesco MIL assessment frameworks

\begin{tabular}{|c|c|c|c|}
\hline \multicolumn{2}{|c|}{ Unesco $(2013, p .47)$} & \multicolumn{2}{|c|}{ Europe (Celot \& Pérez, 2009, pp. 34-50) } \\
\hline $\begin{array}{c}\text { Tier I: } \\
\text { MIL Country } \\
\text { Readiness }\end{array}$ & $\begin{array}{l}\text { Tier II: } \\
\text { MIL Competencies }\end{array}$ & $\begin{array}{l}\text { Environmental Factors } \\
\text { (for MIL) }\end{array}$ & Personal Competences \\
\hline $\begin{array}{l}\text { 1. MIL education } \\
\text { 2. MIL policy } \\
\text { 3. MIL supply } \\
\text { 4. MIL access and } \\
\text { use, and civil } \\
\text { society }\end{array}$ & $\begin{array}{l}\text { 1. Access and re- } \\
\text { trieval } \\
\text { 2. } \\
\text { Understanding } \\
\text { and } \\
\text { evaluation } \\
\text { 3. Creation and } \\
\text { sharing }\end{array}$ & $\begin{array}{l}\text { Media literacy context: } \\
\text { 1. Media education (pre- } \\
\text { sence in curriculum, tea- } \\
\text { cher training) } \\
\text { 2. Media literacy policy (re- } \\
\text { gulation) } \\
\text { 3. Media industry } \\
\text { 4. Civil society and Media } \\
\text { availability (mobile pho- } \\
\text { ne; Internet; television; } \\
\text { radio; newspapers; } \\
\text { cinema) }\end{array}$ & $\begin{array}{l}\text { Use: } \\
\text { 1. Computer and Internet } \\
\text { skills } \\
\text { 2. Balanced use of media } \\
\text { 3. Advanced Internet use } \\
\text { Critical Understanding: } \\
\text { 1. Understanding media } \\
\text { content and its } \\
\text { functioning } \\
\text { 2. Knowledge of media and } \\
\text { regulation } \\
\text { 3. User behavior }\end{array}$ \\
\hline
\end{tabular}

MIL competency

Cognitive elements: attitudes (rights, principles, values and attitudes), knowledge and skills.

Which "together play an important role in the MIL Assessment Framework, as they do in the learning and teaching processes, and in relation to employment, for participation and empowerment in societal life". (2013, p. 47).

\section{Communicative skills}

Social relations, citizen participation and content creation "Social relationships demonstrate the potential for individual and group relationships via the media. [...] the media manages social groups and dictates the type of frequency of contact [...] [cooperation or conflict] among them". (2009, p. 44).

Source: Pérez-Tornero (2007), Durán-Becerra \& Tejedor-Calvo (2015, p. 145).

use of ICT. The National Assessment Program - ICT Literacy (NAP-ICTL) measures at the same time technological skills, IL skills, and knowledge in the general use of information. This with the purpose of generating communication skills (Ainley, Fraillon, Gebhardt, \& Schulz, 2012, pp. 7-8), with an understanding of the set of characteristics and scenarios created by new technologies as an ecosystem which may generate opportunities and advantages (Katz \& Koutroumpis, 2013).

Following the above-mentioned, this research establishes one general and three specific objectives. The general objective, as has been previously introduced, is to explore, analyze, and systematize the principal MIL related frameworks, research 
reports, and their practical applications. MIL must be understood as a complex concept, not only because it tries to integrate three dimensions and fields of study into one; it also has to be seen as a holistic approach that includes previous research close to the field (or in the same one), such as Educommunication (De Oliveira Soares, 2009), multiple literacies, new literacies and other related concepts that enrich its understanding and broaden its scope and reach globally

Specific objectives are to explore current literature on MIL; provide a broad understanding of the three principal approaches to MIL (media, information, and digital literacies) and; lastly, create a map of the MIL skills and competencies derived from the main theories reviewed.

\section{Method}

The approach in this article is based on a qualitative content analysis to map and systematize the principal MIL frameworks, research reports and practical applications of these frameworks. Therefore, categories (dimensions) are combined and correlated to establish individual indicators (skills and capabilities) and group them in subcategories (components) (tables 3 and 4). The meta-analysis is based on eighteen published works on MIL indicators and competencies that study frameworks and the disaggregation of indicators (Durán-Becerra, 2016). This paper also includes the analysis of three publications issued after the first study was published (Petranová et al., 2017; Frau-Meigs et al., 2017; Lopes et al., 2018). Thus, the research provides a good understanding of the three principal approaches linked to MIL (media, information and digital literacies) and the exploration of assessment proposals and systematization of indicators that develop the main MIL frameworks from the European Commission, Unesco, the Association of College and Research Libraries, the Australian Curriculum, Assessment and Reporting Authority and tests such as A Media Literacy Quiz, B2i Brevet Informatique et Internet, the European Union survey on ICT usage, the PIAAC Background Questionnaire and PISA, among others - Similar outcomes from the analysis of these frameworks can be observed in Lopes et al. (2018), in their case to create a MIL test-.

The content analysis allows a good understanding of the meaning of different concepts and approaches to MIL as it explores their communicative context and social and cognitive senses. That is, the meaning or hidden/unveiled meaning a concept or speech has, which is related to their social, cultural, psychological, or historical production-consumption circumstances (Piñuel, 2002). Three major dimensions (categories) were set according to the initial literature review: media, information, and digital literacies (table 3). These dimensions, in turn, were composed by the following components: information priority; access; evaluation (critical comprehension); use; advanced use and limits/responsibilities (under the information dimension); use and 
advanced use (under the digital dimension); critical comprehension of media/knowledge of media's context, use, critical comprehension, advanced use, citizen participation/ empowerment, limits/responsibilities (under the media dimension). In the end, these categories and subcategories led to a systematization and proposal of the main MIL related skills and capabilities (table 4).

OverviewDocs, an opensource Quantitative Descriptive Analysis (QDA) software was used to systematize and aggregate the skills and capabilities, which allowed the identification of referents, frameworks and academic research that support the proposed map of MIL skills and competences. OverviewDocs ODA was used by tagging skills and capabilities matching the different dimensions and components. The software aggregated the combinations gathered in a range of visualization tools included as default. The data were double validated to avoid any biases and downloaded in .xlsx format to process it in tables.

The methodological proposition is summarized in four tables included in this article (tables 1 to 4). The first one frames the general concept of MIL for evaluation purposes; the second one formulates a specific definition of the competences in question; the third one presents a summary of the dimensions and components of MIL; and the fourth one summarizes the final proposal, which includes a map of the MIL skills and competences derived from the main theories that were reviewed.

\section{Results}

In 2008, Unesco (2008, p. 19) proposed a series of parameters for the creation of IL indicators, building a "Map [or Constellation] of Communication Skills" divided into five levels of observation with different skills (which summarizes the propositions of Catts and Lau from 2009: information skills, skills in ICT, media skills, oral communication skills, and reasoning skills). On the other hand, in their study for the European Commission, Celot and Pérez (2009) initially established a formal approach to the evaluation of the MIL levels through a scheme that groups together individual competencies (use, understanding, critical thinking, communication skills) and praises the environmental factors (existence of policies in/for the media/media education, availability of the media and relation of the media industry with civil society) (PérezTornero \& Durán Becerra, 2019). Unesco (2011b) explains that the described dimensions are grouped in two categories that define processes of measurement/assessment or generation of indicators. Category 1 refers to the factors that facilitate information development. Category 2 approaches those factors which create conditions of creation, availability, distribution, supply, and reception of information. It proposes three skill components that have a similar structure that serve to establish indicators for personal capacities (access, evaluation, and use). 


\section{Studies and Approaches to MIL}

The different competencies in MIL research measurements may be grouped as part of DL (Digital Literacy), IL or ML. According to researcher Renee Hobbs (2010, p. 17), in the last fifty years, there have been enormous advances made in the theoretical field of media education due to the emergence of ICT. The existing typologies are a result of the spectrum created in different frameworks proposed by actors in relation to education policies, curricula, evaluation schemes or other types of academic activities (Pérez-Tornero \& Durán-Becerra, 2019). These frameworks are an output from the concern to incorporate ICT in different social scenarios (Giraldo-Luque et al., 2014, p.7; Kanižaj, 2017).

An example of the aforesaid is the Development of Indicators on Individual, Corporate and Citizen Media Literacy research (Dynamic) -a study of the Office of Communication and Education of the Universidad Autónoma de Barcelona, financed by the Spanish Ministry of Science and Innovation and directed by professor José Manuel Pérez Tornero- that analyzed 17 studies on the evaluation of competences related to MIL (Giraldo-Luque et al., 2014). The study confirms a trend towards the assessment of digital skills: 11 out of 17 studies work with aspects of DL, 6 of ML and 4 of IL. Out of the 696 questions individually analyzed, 280 focus on the component of use, 185 on critical thinking, 92 on communication skills, 79 on the availability of resources and 60 on the context for ML (Giraldo-Luque et al., 2014, p. 11).

Another basic reference for the creation of indicators to assess MIL levels is the report by the European Association for Viewers Interests and Universidad Autónoma de Barcelona (EAVI-UAB) for the European Commission (Celot \& Pérez-Tornero, 2009, p. 35). This research model outlines specific criteria, components and indicators (Pérez-Tornero \& Durán-Becerra, 2019). Ferrès and Piscitelli (2012, pp. 79-81), on the other hand, establish dimensions for MIL evaluation, they emphasize fields of analysis and fields of expression, studying the dimensions of: language, technology, interaction, production and diffusion, ideology and values and aesthetics. Renee Hobbs (2010, p. 19) proposes a map of essential competencies to design programs or evaluations for Digital and Media Literacy. These essential competencies (table 2) are core to many studies and have been part of large sets of MIL tests and assessment schemes proposed by different MIL actors (Lopes et al., 2018).

The components described by Hobbs are similar to the proposals outlined in the previous paragraph, giving special importance to access, which in turn relates to the availability of infrastructure, and the individual capabilities on use (table 2). Likewise, the component understood as analysis and/or evaluation extends to what other authors describe as critical thinking (Frau-Meigs, 2012). In relation to the capabilities described above, Hobbs highlights the capability to create, describing it as an advanced use, which implies the possibility of generating content and interacting with platforms. The com- 
ponent related to the reflexive capabilities includes another frequently discussed research concern related to ethics of the communication processes (an aspect which has also included protectionist proposals concerning the use and consumption of media). Finally, the capability of acting, constructed on the latent objective of MIL, will impact the improvement of decision-making, to generate greater citizen involvement and thus promote their social participation (Culver $\&$ Jacobson, 2012; Giraldo-Luque et al., 2017).

Table 2. Essential Competences of Digital and Media Literacy

\begin{tabular}{ll}
\hline 1. Access & \multicolumn{1}{c}{ Essential Competences } \\
\hline Finding and using media and technology tools skillfully and sharing appro- \\
priate and relevant information with others.
\end{tabular}

Source: Hobbs (2010, p. 19).

\section{Framework of MIL Competences}

This section describes a classification of dimensions and components by outlining a comparative map of competences and skills. It gathers the contributions of the Association of College and Research Libraries (ACRL, 2000, p. 5), the Australian Curriculum, Assessment and Reporting Authority Acara (Ainley et al., 2012, p. 7), Pérez-Tornero (2007, pp.18-19), Unesco (2008), Celot and Pérez-Tornero (2009, pp. 34-50), Lau and Cortés (2009); Hobbs (2010, p. 19), Unesco (2011b, pp. 14-15; 2013, pp. 56-60) and Giraldo-Luque et al. (2014) ', as well as the findings of Emedus (Durán-

\footnotetext{
This study gathers the main contributions of the following studies: "A Media Literacy Quiz"; "B2i Brevet Informatique et Internet"; "Better Public Services through e-government"; "Bibliotecas escolares, ¿entre interrogantes? Herramienta de autoevaluación" (School Libraries. Between question marks? A tool for Self-evaluation); "Community survey on ICT usage and e-commerce in enterprises"; "Competencia mediática. Investigación sobre el grado de competencia en la ciudadanía en España" (Media competence. Research on the degree of competence in the citizenry in Spain); "E-skills career tool: linking ICT skills to Jobs"; "European Union survey on ICT usage in households and by individuals"; "Identify your ICT needs"; "IT Card"; National Assessment Program. ICT Literacy 2011; Nonprofit Social Media Policy Workbook; PIAAC Background Questionnaire; PISA 2009; "Survey of Schools: ICT in Education". "Benchmarking Access, Use and Attitudes to Technology in Europe's Schools"; "Testing and refining criteria to assess media literacy levels in Europe".
} 
Becerra \& Tejedor-Calvo, 2015; Petranová et al, 2017), ANR Translit and COST projects (Frau-Meigs et al., 2017).

Table 3, shown below, is a summary that simplifies the variables observed by the different theoretical frameworks previously analyzed (dimensions). In turn, each of the components defines skills and competences. The components of each of the studied literacies (dimensions), as well as their related skills, are explored in full in table 4 and explained in the following paragraphs.

Table 3. Summary of the MIL Dimensions and Components

\begin{tabular}{ll}
\hline \multicolumn{1}{c}{ Dimension } & \\
\hline & A1. Information priority \\
& A2. Access \\
A. Information & A3. Evaluation (critical comprehension) \\
& A4. Use \\
& A5. Advanced use \\
& A6. Limits/ responsibilities \\
\hline \multirow{3}{*}{ B. Digital } & B1. Use \\
& B2. Advanced use \\
& C1. Use \\
C2. Critical comprehension \\
C3. Critical understanding of media / knowledge of media's context \\
C4. Advanced use \\
C5. Citizen participation / empowerment \\
C6. Limits/ responsibilities
\end{tabular}

Source: Durán-Becerra (2016, p. 135).

In table 4, the first dimension (A) comprises the components related to information literacy. The component (Al) of information priority is defined as the capability to determine the amount of information needed for the development of a specific task or project (ACRL, 2000, p. 5; Unesco, 2008; 2011b, p. 14; Lau \& Cortes, 2009). It is a set of skills that allows the correct management of information (Ainley et al., 2012), the identification of the specific information requirements for performing a task, or for the fulfillment of an information need. The access component (A2) deals with the capability to access information in an efficient and effective manner while knowing the means of access (mechanisms, platforms, codes, etc.), ensuring agility and satisfaction of the specific information needs (ACRL, 2000, p. 5; Unesco, 2008; Ainley et al., 2012). Pérez-Tornero (2007, pp. 18-19) emphasizes the physical access to media and its contents, which implies the existence and possession of technological components and equipment (Celot \& Pérez-Tornero, 2009, pp. 34-50). This is understood as opportunities (which implies an element of context and not only skill) (Lau \& Cortes, 2009; Hobbs, 2010, p. 19; Unesco, 2013, pp. 56-60). 
The evaluation component (A3), also described as critical comprehension, deals not only with critically evaluating the consulted/consumed information, but also the resources employed, so they can be efficiently transformed into knowledge (ACRL, 2000, p. 5; Ainley et al., 2012). It integrates a set of skills necessary to judge the integrity, relevance and benefits of information, while being supported by ICT tools. The evaluation and critical reading capabilities (technical and cognitive) are skills to read, understand and evaluate the offered media products and contents (Pérez-Tornero, 2007, pp. 18-19; Unesco, 2008). It is also the capability to classify audiovisual and written texts (into typologies and formats) to differentiate content, classify and validate webpages/sites, with the objective of inducing and deducing information elements/ideas (Lau $\&$ Cortés, 2009; Hobbs, 2010, p. 19; Celot \& Pérez-Tornero, 2009, p. 35). Unesco (2013, pp. 5660 ) indicates that the processes of IL shape the skills for healthy media consumption.

The component of use (A4) is defined as the set of skills that allow the collection of information for a specific purpose (ACRL, 2000, p. 5), towards the creation of new knowledge (Ainley et al., 2012). The capability of communicating the use of the consulted information (Unesco, 2008, 2011b, pp. 14-15) favors processes of creation, information processing (evaluation/understanding), application of acquired knowledge and reproduction of consulted/recovered information (Lau \& Cortes, 2009; Hobbs, 2010, p. 19; Unesco, 2013, pp. 56-60; Giraldo-Luque et al., 2014).

The fifth element (A5) is advanced use, related to the responsible use of ICT (Ainley et al., 2012) with more complex communication processes, such as the capability of exchanging information and knowledge and/or creating information products adjusted to the audience, context and medium in an ethical manner (Unesco, 2008; 2011b, pp.14-15; Lau \& Cortés, 2009). It implies identifying procedures and behaviors related to online security and protection (Celot \& Pérez-Tornero, 2009, p. 35). It also links individual capabilities focused on promoting participation in public and social activities as active citizens (Unesco, 2013, pp. 56-60). The last component (A6) within this dimension is concerned with the limits and responsibilities that the individual ought to understand in regard to the legal, economic, and social context surrounding information, with the aim of respecting the rights, duties and responsibilities derived from the author rights, as well as their ethical and legal use (ACRL, 2000, p. 5; Unesco, 2008; 2011b, pp. 14-15; 2013; Lau \& Cortes, 2009).

The second dimension (B) is associated with DL, which is constantly linked to Information and Media literacies. In Promoting Digital Literacy (Pérez-Tornero, 2004, pp.18-19) the component of use (Bl) is defined as the physical access to media and its content and meaning, in other words as the real possibility of use that allows the user to consult and handle resources (Durán-Becerra, 2016). This set of skills are mostly technical and are described by Unesco (2008) as every skill which allows the use of 
ICT, basically computer and Internet-browsing skills (Celot $\&$ Pérez-Tornero, 2009, pp. 34-50). In 2011, Unesco (2011b, pp. 14-15; Giraldo-Luque et al., 2014) started emphasizing that the digital component deals with using ICT to process information and produce user-generated content (Leaning, 2017; Lopes et al., 2018). The advanced use component (B2) is then defined as the set of capabilities/skills necessary for the design and construction of ICT solutions for the storing of information and the making of ICT decisions that are critical, strategic and reflective (advanced and balanced use) (Ainley et al., 2012, p. 7; Durán-Becerra, 2016).

The third dimension $(\mathrm{C})$ is Media, whose first component $(\mathrm{Cl})$ studied within this dimension is use. It is defined as the cognitive and practical skills that allow the proper enjoyment of media (Pérez-Tornero, 2007, pp. 18-19), and the understanding of different kinds of communication tools and networks (informative, social, professional) (Unesco, 2008). It also highlights the skills related to the use of the Internet (Celot $\varepsilon$ Pérez-Tornero, 2009, p. 35; Unesco, 2013, pp. 56-60; Giraldo-Luque et al., 2014). Renee Hobbs (2010, p. 19), in turn, directly relates use with access as a first step, and with the capability of accessing, consulting, using and generating content, in a second moment.

The second component ( $\mathrm{C} 2$ ) is related to critical comprehension, which implies the understanding of content and information, and the conscious consumption of cultural and media products. It is a set of skills to read, understand and evaluate media content and products as defined by Pérez-Tornero (2007, pp. 18-19) and understood by Unesco (2008, 2013, pp. 56-60). Hobbs (2010, p. 19) emphasizes the components of analysis and evaluation of information (reading competence), which are also highlighted in other studies that aggregate various researches (Celot \& Pérez-Tornero, 2009, pp. 35-36; Giraldo-Luque et al., 2014).

The third component (C3) is the critical understanding of media meaning and/or knowledge of the context of media. This factor includes capabilities of understanding the functioning of media and its content, as well as critical identification of media content and concentration of media ownership (or its plurality) (Vedel, García-Graña, E Durán-Becerra, 2017; Celot \& Pérez-Tornero, 2009, pp. 34-50). This concept implies having knowledge of the regulation of media, of its authorities, and penalizing procedures related to media. In the words of Thierry Vedel, also the "basic protection, market plurality, political independence and social inclusiveness" of media (Vedel et al., 2017, p. 3). Unesco (2011b, pp. 14-15) and different studies on MIL policy (Frau-Maigs et al., 2017; Pérez-Tornero \& Durán-Becera, 2019) also highlight the need of knowing the role and functions of media in democratic societies (Orozco, 1997).

The fourth component of this dimension, advanced use (C4), is understood as in the information dimension: it entails advanced actions on the use of technology and 
therefore, the digital dimension (Pérez-Tornero, 2007, pp. 18-19; Ainley et al., 2012, p. 7). It is the capability of making critical, strategic and reflective ICT decisions (Celot $\varepsilon$ Pérez-Tornero, 2009, pp. 34-50). This component implies sophistication of the web, the use of the Internet for online government cooperation or services, and also a component of protection and security (Giraldo-Luque et al., 2017).

The fifth component (C5) is about citizen participation and empowerment. This component has also been identified with the concept of "user-centrism" (Celot $\varepsilon$ Pérez-Tornero, 2009, pp. 34-50), expressed, among other things, by the use of public services online. It implies the capability of acting collectively and individually to share knowledge and solve problems, and to participate as a member of local, regional, national and international communities (Hobbs, 2010, p. 19). It may be understood as the capability to use media for personal expression and democratic participation (Unesco, 2011b, pp. 14-15, 2013; Giraldo-Luque et al., 2014).

Lastly, the sixth component, limits and responsibilities (C6), is understood as the capability of valuing the social, legal and ethical nature of the problems treated by media and handled/used and reproduced by other agents (media-related or otherwise) and by users, as well as their regulation (Ainley et al., 2012, p. 7; Celot \& Pérez-Tornero 2009, pp. 34-50). Renee Hobbs (2010, p. 19) establishes that this component is related to the different skills that allow a person to reflect on the uses, information scope, ethics and social responsibility of our communication behavior and conduct.

\section{Proposed MIL Dimensions for Evaluation Purposes}

Keeping in mind the characteristics of each of the described dimensions, the following map of MIL skills and competences is proposed under a holistic approach to media and information components (Durán-Becerra, 2016):

Table 4. Map of MIL Skills and Competences

\begin{tabular}{|c|c|c|}
\hline Dimension & Component & Skill / Capability \\
\hline \multirow{7}{*}{ A. Information } & $\begin{array}{l}\text { A1. Information priori- } \\
\text { ty }\end{array}$ & Identifying information needs. \\
\hline & \multirow{4}{*}{ A2. Access } & Seeking/locating information and contents. \\
\hline & & Accessing information and contents. \\
\hline & & Recovering and storing information and contents. \\
\hline & & Organizing and systematizing information. \\
\hline & \multirow{2}{*}{$\begin{array}{l}\text { A3. Evaluation } \\
\text { / critical } \\
\text { comprehension }\end{array}$} & $\begin{array}{l}\text { Understanding (reading comprehension) the consulted con- } \\
\text { tents and information. }\end{array}$ \\
\hline & & Evaluating the consulted information. \\
\hline
\end{tabular}




\begin{tabular}{|c|c|c|}
\hline Dimension & Component & Skill / Capability \\
\hline \multirow{12}{*}{ A. Information } & \multirow{4}{*}{$\begin{array}{l}\text { A3. Evaluation / cri- } \\
\text { tical comprehen- } \\
\text { sion }\end{array}$} & Evaluating the source/provider of information. \\
\hline & & Evaluating the consulted resource. \\
\hline & & Differentiating types and formats of texts. \\
\hline & & Classifying and validating localized webpages/sites. \\
\hline & \multirow{3}{*}{ A4. Use } & Using the consulted information with a specific purpose. \\
\hline & & Creating, sharing and reproducing information and contents. \\
\hline & & Applying learned contents. \\
\hline & \multirow{4}{*}{ A5. Advanced use } & $\begin{array}{l}\text { Using the consulted or produced information and resources } \\
\text { ethically. }\end{array}$ \\
\hline & & $\begin{array}{l}\text { Using ICT resources and services for information and content } \\
\text { creation responsibly. }\end{array}$ \\
\hline & & $\begin{array}{l}\text { Participating in social or political activities through networks } \\
\text { or in person, in an informed manner. }\end{array}$ \\
\hline & & $\begin{array}{l}\text { Monitoring the influencing capacity and effects of consumed } \\
\text { media and information. }\end{array}$ \\
\hline & $\begin{array}{l}\text { A6. Limits/responsibi- } \\
\text { lities }\end{array}$ & $\begin{array}{l}\text { Understanding the legal, economic and social context of } \\
\text { information, content and the media (rights, duties, respon- } \\
\text { sibilities). }\end{array}$ \\
\hline \multirow{8}{*}{ B. Digital } & \multirow{3}{*}{ B1. Use } & Accessing information/ICT skills. \\
\hline & & Using Internet for general purposes. \\
\hline & & Creating and consuming content and information. \\
\hline & \multirow{5}{*}{ B2. Advanced use } & Using online banking. \\
\hline & & Buying products online. \\
\hline & & Online working. \\
\hline & & $\begin{array}{l}\text { Studying online (eLearning/education use of digital learning } \\
\text { platforms). }\end{array}$ \\
\hline & & $\begin{array}{l}\text { Generating complex ICT tools (programming skills and te- } \\
\text { chnical analysis). }\end{array}$ \\
\hline \multirow{7}{*}{ C. media } & C1. Use & $\begin{array}{l}\text { Cognitive capabilities that allow the use of media and } \\
\text { Information. }\end{array}$ \\
\hline & & Using communication tools. \\
\hline & & Using social networks. \\
\hline & & Using Internet. \\
\hline & & Consuming online news. \\
\hline & & Creating content. \\
\hline & & $\begin{array}{l}\text { Accessing, creating and reproducing information and } \\
\text { content. }\end{array}$ \\
\hline
\end{tabular}




\begin{tabular}{|c|c|c|}
\hline Dimension & Component & Skill / Capability \\
\hline \multirow{23}{*}{ C. media } & \multirow{6}{*}{$\begin{array}{l}\text { C2. Critical compre- } \\
\text { hension }\end{array}$} & $\begin{array}{l}\text { Reading, understanding and evaluating media, information } \\
\text { or cultural content. }\end{array}$ \\
\hline & & Classifying types and formats of texts. \\
\hline & & Understanding the behavior of users. \\
\hline & & $\begin{array}{l}\text { Classifying webpages/sites according to type and properties } \\
\text { (quality, officials, etc.). }\end{array}$ \\
\hline & & $\begin{array}{l}\text { Classifying digital platforms and understanding their cha- } \\
\text { racteristics. }\end{array}$ \\
\hline & & $\begin{array}{l}\text { Being mindful of the functioning and interests of media and } \\
\text { providers when consuming contents/resources in general. }\end{array}$ \\
\hline & \multirow{3}{*}{$\begin{array}{l}\text { Critical unders- } \\
\text { tanding of media / } \\
\text { knowledge of the } \\
\text { media's context }\end{array}$} & $\begin{array}{l}\text { Understanding how the media works (functioning logics, } \\
\text { interests, belonging to corporate groups). }\end{array}$ \\
\hline & & $\begin{array}{l}\text { Understanding the regulations governing media, especially } \\
\text { on the contents, information and cultural goods in general. }\end{array}$ \\
\hline & & $\begin{array}{l}\text { Understanding the characteristics of the media's environ- } \\
\text { ment (political system, concentration, plurality). }\end{array}$ \\
\hline & \multirow{6}{*}{ C4. Advanced use } & $\begin{array}{l}\text { Participating in advanced uses of the Internet (purchases, } \\
\text { online work, etc.). }\end{array}$ \\
\hline & & $\begin{array}{l}\text { Using media in a balanced way (comprehensively, conside- } \\
\text { ring limitations and responsibilities, and without generating } \\
\text { dependency). }\end{array}$ \\
\hline & & Creating contents according to audiences. \\
\hline & & Creating interactive and creative contents. \\
\hline & & $\begin{array}{l}\text { Making advanced ICT decisions (security, programming, } \\
\text { ethical and legal use). }\end{array}$ \\
\hline & & $\begin{array}{l}\text { Using the information, contents and consulted/created media } \\
\text { ethically and responsibly. }\end{array}$ \\
\hline & \multirow{5}{*}{$\begin{array}{l}\text { C5. Citizen participa- } \\
\text { tion / empower- } \\
\text { ment }\end{array}$} & $\begin{array}{l}\text { Participating in social or political activities through networks } \\
\text { or in person, in an informed manner (active citizenship). }\end{array}$ \\
\hline & & Using government services online. \\
\hline & & $\begin{array}{l}\text { Monitoring the influencing capacity and effects of the con- } \\
\text { sumed information/media. }\end{array}$ \\
\hline & & Using the Internet to promote cooperation. \\
\hline & & $\begin{array}{l}\text { Using web-based services (social networks, requests, media, } \\
\text { etc.) for the demonstration of opinions and political control. }\end{array}$ \\
\hline & \multirow{3}{*}{$\begin{array}{l}\text { C6. Limits/ responsibi- } \\
\text { lities }\end{array}$} & $\begin{array}{l}\text { Knowing the regulations governing media and the responsi- } \\
\text { bilities deriving from it. }\end{array}$ \\
\hline & & $\begin{array}{l}\text { Knowing the regulating authorities and the legal procedures } \\
\text { to interpose complaints or appeals. }\end{array}$ \\
\hline & & $\begin{array}{l}\text { Understanding copyright (intellectual property, economic } \\
\text { rights and use/reproduction rights). }\end{array}$ \\
\hline
\end{tabular}

Source: Durán-Becerra (2016, pp. 146-148) 
This map of MIL skills and competencies is the result of the analysis of the sets of skills, variables, capacities and observation units proposed by the authors and organizations referred earlier in the paper. Aggregated under three single dimensions, the map offers a systematization that will allow further research on MIL curriculum design, MIL evaluation or assessment tools, MIL policy guidelines and similar outcomes. Similarly, it is understood as a guide of dimensions for evaluation purposes, but its effectiveness is still to be set. Skills and competencies described derive from a robust examination and systematization that takes into account some of the most relevant studies and frameworks on MIL.

\section{Conclusions}

The work of international institutions and world-renowned organizations has been crucial in the development of Media and Information Literacy as a discipline. The role of researchers and universities has been supported by this kind of institutions; therefore, the construction of frameworks for the measurement or creation and design of strategies to strengthen MIL competences is the result of such individual and institutional foundations. The identification of MIL competencies is also the result of different efforts that have yielded some construct proposals for evaluation and assessment.

However, the research scope of such works is not easily assessable, because studies on measurement of competencies generally imply emphasizing the digital component on the use of technology in the processes surrounding media consumption and use of computers in different routines and citizen daily activities, while including components related to the creative and constructive capability of digital tools. Therefore, the need to promote behaviors, and critical and responsible use of both media and information content is normally left aside -a gap that is addressed in the MIL map proposed in this paper-.

In any case, the limitations of other frameworks may be given by the complexity and plurality of definitions surrounding MIL. The competency framework exercise proposed in this paper focuses on strengthening critical skills that allow citizens to have a better adaptation to its social space and promoting their active participation and contribution to MIL processes. This compilation has the goal to set a model for future evaluation proposals and a guide to introduce MIL in national curricula and education policies. Its viability and strengths lie in its ample work and systematization of the current MIL conceptualizations and research.

Even though the need for further research is a must, competency evaluation and systematization exercises like the offered here allows a better understanding of the complexity of the subject and the urgency to improve its framework. In this sense, the scheme proposed in the MIL map of skills and competences constitutes a structu- 
red effort to enable the creation of a next generation of methodologies and strategies for the visibility, promotion, strengthening and evaluation of MIL.

\section{References}

Association of College and Research Libraries (ACRL). (2000). Information Literacy Competency Standards for Higher Education. American Library Association.

Ainley, J., Fraillon, J., Gebhardt, E., E Schulz, W. (2012). National assessment program: ICT literacy technical report (NAP-ICTL). Australian Curriculum, Assessment and Reporting Authority (Acara).

Catts, R., E Lau, J. (2009). Hacia unos indicadores de Alfabetización Informacional. Ministerio de Cultura de España.

Celot, P. E Pérez, J. M. (2009). Study on assessment criteria for media literacy levels. A comprehensive view of the concept of media literacy and an Understanding of how media literacy level in Europe Should Be Assessed. European Commission.

Culver, S. H. E Jacobson, T. (2012). Alfabetización mediática como método para fomentar la participación cívica. Comunicar, 20(39), 73-80. https://doi.org/10.3916/C39-2012-02-07

De Oliveira Soares, I. (2009). Caminos de la educomunicación: utopías, confrontaciones, reconocimientos. Nómadas, (30), 194-207. http://www.scielo.org.co/scielo.php?pid=S0121 75502009000100015 Escript $=$ sci_abstractEtlng $=$ en

Durán-Becerra, T. (2016). AMI en Latinoamérica Aproximación, análisis y propuesta de medición sobre el contexto de la Alfabetización Mediática e Informacional en América Latina. Universitat Autònoma de Barcelona.

Durán-Becerra, T. E Tejedor-Calvo, S. (2015). Implementación curricular de la Alfabetización Mediática en Europa. Principales resultados del proyecto Emedus. En J.M. Pérez-Tornero, A. Fuelles Gutiérrez, \& C. Rodríguez-Hoyos, C. (coords), Los territorios de la educación mediática. Editorial UOC.

Durán-Becerra, T. E Tejedor-Calvo, S. (2017). Interaction in educommunicational platforms. A reflection on different types of platforms and their usability. The case of Colombia. TEKNOKULTURA: Revista de cultura digital y movimientos sociales, 14(2), 261-275. https://revistas. ucm.es/index.php/TEKN/article/download/55735/52583

European Commission (2007). Communication from the Commission to the Council, the European Parliament, the European Economic and Social Committee and the Committee of the Regions. E-skills for the 21 st Century: Fostering Competitiveness, Growth and Jobs. European Commission. https://www. eea.europa.eu/policy-documents/communication-from-the-commission-to- 1

European Commission. (2009). Commission Recommendation on media literacy in the digital environment for a more competitive audiovisual and content industry and an inclusive knowledge society. European Commission. https://eur-lex.europa.eu/legal-content/EN/TXT/PDF/?uri=CELEX:32009H0625 $\varepsilon$ from $=\mathrm{EN}$

Ferrés, J. E Piscitelli, A. (2012). La competencia mediática: propuesta articulada de dimensiones e indicadores. Comunicar, 19(38), 75-82. https://doi.org/10.3916/C38-2012-02-08 
Frau-Meigs, D. (2012). Transliteracy as the New Research Horizon for Media and Information Literacy. Medijskestudije, 3(6), 14-26. https://hrcak.srce.hr/96345

Frau-Meigs, D., Velez, I. E Michel, J. F. (eds.). (2017). Public policies in media and information literacy in Europe: cross-country comparisons. Taylor \& Francis.

Giraldo-Luque, S., Durán-Becerra, T., Esteban, A. E Villegas, I.M. (2014). MIL Competences: from theory to practice. Measuring citizens' competences on Media and Information Literacy. eLearning Papers, 38, 18-30. https://dialnet.unirioja.es/servlet/articulo?codigo $=6360727$

Giraldo-Luque, S., Villegas-Simón, I. E Durán-Becerra, T. (2017). Uso de los sitios web de los parlamentos para promover la deliberación ciudadana en el proceso de toma de decisiones públicas. Estudio comparado de diez países (América y Europa). Communication E Society. 30(4), 77-97. https://dadun.unav.edu/handle/10171/54611

Hobbs, R. (2010). Digital and Media Literacy: A Plan of Action. A White Paper on the Digital and Media Literacy Recommendations of the Knight Commission on the Information Needs of Communities in a Democracy. The Aspen Institute.

Kanižaj, I. (2017). The role of civil society organisations in promoting media literacy, transliteracy and media and information literacy in EU. Revista Fuentes, 19(2), 69-80. https://doi.org/10.12795/ revistafuentes.2017.19.2.05

Katz, R. L. E Koutroumpis, P. (2013). Measuring digitization: A growth and welfare multiplier. Technovation, 33(10-11), 314-319. https://doi.org/10.1016/j.technovation.2013.06.004

Koltay, T. (201 1). The media and the literacies: Media literacy, information literacy, digital literacy. Media, Culture E Society, 33(2), 211-221. https://doi.org/10.1177/0163443710393382

Lau, J. E Cortés, J. (2009). Habilidades informativas: convergencia entre ciencias de información y comunicación. Comunicar, 16(32), 21-30. https://doi.org/10.3916/c32-2009-02-001

Lau, J. \& Grizzle, A. (2019). Media and Information Literacy: Intersection and Evolution, A Brief History. In S. Goldstein (2019), Informed societies - why information literacy matters for citizenship, participation and democracy'. Facet.

Leaning, M. (2017). Media and information literacy: An integrated approach for the 21 st century. Chandos Publishing.

Literat, I. (2014). Measuring New Media Literacies: Towards the Development of a Comprehensive Assessment Tool. Journal of Media Literacy Education, 6(1), 15-27. https://digitalcommons.uri. edu/cgi/viewcontent.cgi?article $=1141$ \&context $=$ jmle

Lopes, P., Costa, P., Araujo, L., E Ávila, P. (2018). Measuring media and information literacy skills: Construction of a test. Communications, 43(4), 508-534. https://doi.org/10.1515/ commun-2017-0051

Orozco, G. (1997). Medios, audiencias y mediaciones. Comunicar, (8), 25-30. https://www.redalyc. org/pdf/158/15800806.pdf

Pérez-Tornero, J. M. (2004). Promoting Digital Literacy. Universidad Autónoma de Barcelona.

Pérez-Tornero, J. M. (2007). Study on the Current Trends and Approaches to Media Literacy in Europe. Universidad Autónoma de Barcelona. 
Pérez-Tornero, J. M. E Durán-Becerra, T. (2019). European Perspectives on Media Literacy. In The International Encyclopedia of Media Literacy (vol. 1, pp. 1-8). Wiley. https://doi. org/10.1002/9781118978238.ieml0066

Petranová, D., Hossová, M. E Velický, P. (2017). Current development trends of media literacy in European Union countries. Communication Today, 8(1), 52-65. https://www.communicationtoday. sk/download/1 2017/PETRANOVA-HOSSOVA-VELICKY-\%25E2\%2580\%2593-CT-1-2017.pdf

Piñuel Raigada, J. L. (2002). Epistemología, metodología y técnicas del análisis de contenido. Sociolinguistic Studies, 3(1), 1-42. https://www.ucm.es/data/cont/docs/268-2013-07-29-Pinuel_ Raigada_AnalisisContenido_2002_EstudiosSociolinguisticaUVigo.pdf

Ponjuán, G., Pinto, M. E Uribe-Tirado, A. (2015). Conceptualización y perspectivas de la alfabetización informacional en Iberoamérica: un estudio Delphi. Information Research, 20(3), 1 29. http://eprints.rclis.org/28504/1/ALFIN\%20estudio\%20Delphi.pdf

Unesco. (2008). Towards information literacy indicators (R. Catts $\mathcal{E}$ J. Lau, eds.). Unesco. http://originwww.ifla.org/files/assets/information-literacy/publications/towards-information-literacy_2008en.pdf

Unesco. (2011a). Alfabetización Mediática e Informacional, Curriculum para Profesores (A. Grizzle \& C. Wilson, eds.). Unesco. https://informate.campusfad.org/recursos/documentos/AMI_Unesco. pdf

Unesco. (2011 b). Towards Media and Information Literacy Indicators. Background Document of the Expert Meeting (S. Moeller, A. Joseph, J. Lau \& T. Carbo, eds.). Unesco. http://www.unesco.org/new/ fileadmin/MULTIMEDIA/HQ/CI/CI/pdf/unesco_mil_indicators_background_document_2011_ final_en.pdf

Unesco. (2013). Global Media and Information Literacy Assessment Framework: Country Readiness and Competencies. Unesco. http://uis.unesco.org/sites/default/files/documents/global-media-andinformation-literacy-assessment-framework-country-readiness-and-competencies-2013-en. pdf

Uribe-Tirado. A. (2010). La Alfabetización Informacional en Iberoamérica. Una aproximación a su pasado, presente y futuro desde el análisis de la literatura publicada y los recursos web. Ibersid, 4, 165-176. https://www.ibersid.eu/ojs/index.php/ibersid/article/view/3807

Vedel, T., García-Graña, G. E Durán-Becerra, T. (2017). Media pluralism monitor 2016: monitoring risks for media pluralism in EU and beyond: country report: France. European Union Publications Office. https://op.europa.eu/en/publication-detail/-/publication/6570a2fc-e470-1 1e7-974901 aa75ed7 la 1/language-en

Wilson, C. (2012). Media and information literacy: Pedagogy and possibilities. Comunicar, 20(39), 15-24. https://doi.org/10.3916/C39-2012-02-01 